Article

\title{
Exploring the Role of Tourists: Responsible Behavior Triggered by the COVID-19 Pandemic
}

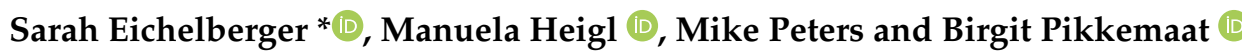 \\ Department of Strategic Management, Marketing and Tourism, SME \& Tourism, University of Innsbruck, \\ Karl-Schönherr-Straße 3, 6020 Innsbruck, Austria; heigl.manuela@hotmail.com (M.H.); \\ mike.peters@uibk.ac.at (M.P.); birgit.pikkemaat@uibk.ac.at (B.P.) \\ * Correspondence: sarah.eichelberger@uibk.ac.at; Tel.: +43-512-507-72458
}

Citation: Eichelberger, S.; Heigl, M.; Peters, M.; Pikkemaat, B. Exploring the Role of Tourists: Responsible Behavior Triggered by the COVID-19 Pandemic. Sustainability 2021, 13, 5774. https://doi.org/10.3390/ su13115774

Academic Editors: Lewis T. O. Cheung and Johnson C. S. Chan

Received: 28 April 2021

Accepted: 18 May 2021

Published: 21 May 2021

Publisher's Note: MDPI stays neutral with regard to jurisdictional claims in published maps and institutional affiliations.

Copyright: (c) 2021 by the authors. Licensee MDPI, Basel, Switzerland. This article is an open access article distributed under the terms and conditions of the Creative Commons Attribution (CC BY) license (https:/ / creativecommons.org/licenses/by/ $4.0 /)$.

\begin{abstract}
Responsible tourism implies that all actors involved in tourism take responsibility for their actions. The concept of responsible tourism has been extensively addressed in tourism research and practice. However, studies analyzing the tourists' contribution to responsible tourism have been neglected. Considering that tourists have the potential to contribute to economic, environmental socio-cultural, and institutional sustainability, this study focuses on the role tourists can play in responsible tourism. It also examines how responsible behavior among tourists has been triggered by the COVID-19 pandemic. Thus, drawing on a planned behavior perspective by concentrating on the tourist contribution to sustainable tourism, responsible tourism behavior is investigated by means of 19 semi-structured interviews. The study found that tourists are not only sensitive to sustainability but that they also behave responsibly both on site and in their travel choices. At the same time, tourists pass the buck to suppliers and providers by requesting rules, information and opportunities for responsible tourism to be created. In this regard, implications for theory and practice can be derived by informing suppliers and providers about their requested responsibilities, as well as by adding a crisis perspective to the Theory of Planned Behavior (TPB).
\end{abstract}

Keywords: tourist responsibility; environmentally responsible behavior; tourist behavior; sustainable tourism; environmental awareness; theory of planned behavior

\section{Introduction}

In the past over-tourism, fast tourism and mass tourism have harmed natural landscapes, environments and regional tourism developments [1]. The excessive exploitation and over-development of tourism can damage a destination's health through impacts on the economy, environment, and society [2]. To balance these tourism impacts, responsible and sustainable tourism is of wide-ranging relevance both in tourism practice and in academic research [3-5]. Even though the current COVID-19 pandemic has placed tourism on hold, discussions around negative tourism impacts will continue to be relevant in the future [6], for instance in the context of past debates regarding over-tourism [7].

Responsible tourism concentrates on minimizing the negative impact of tourism and on optimizing benefits for local communities and environments [8]. It differs from the concept of sustainable tourism by focusing on the responsibility of stakeholders [9], through proper actions and practices [10], resulting in responsible behavior [11]. In this regard, responsible actions by all participants in tourism, be they organizations, individuals, or even governments, are among the requirements for responsible tourism [9].

Previous research on responsible tourism has largely focused on the perspectives of residents and host communities, as well as businesses, while the tourist angle has been neglected [8]. Although environmentally responsible behavior (ERB) has been studied from various perspectives that concentrates on contributions to environmental sustainability [12], responsible tourism behavior provides a broader perspective by also incorporating sociocultural, economic, and institutional dimensions of sustainability. In this regard, tourists 
need to be placed at the center of responsible tourism [13] with a focus on tourists' own responsibility perspectives [14]. Moreover, the current COVID-19 crisis has resulted in the postponement of travel plans for many tourists, a reconsideration of their travel habits and destination choices, and the cancellation of vacations on a grand scale [6]. Thus, recent studies and trend analyses show that the COVID-19 pandemic is affecting travel patterns [15], and is likely to induce a new kind of equilibrium in the psyche of some tourists [16]. According to Higgins-Desbiolles [17] the COVID-19 pandemic has created an opportunity to make tourism more sustainable in the future. Such an opportunity can, however, only be seized if the sustainability perceptions of tourists are fully understood and considered.

This study, therefore, concentrates on the tourists' perspective of responsible tourism [8], while exploring their potential contribution to sustainable tourism, by proposing the following research questions:

- How can tourists contribute to responsible tourism?

- Is the COVID-19 pandemic causing tourists to behave more responsibly?

\section{Theoretical Framework}

\subsection{Responsible Tourism}

During the 1980s, the concept of responsible tourism was introduced by Krippendorf [18] to demonstrate the importance of sociocultural and environmental factors in tourism. Responsible tourism suggests taking responsibility for one's actions and involves various parties including suppliers, tourists, service providers and governments [19]. Fang [4] refers to responsible tourism as, "one way of maximizing the possibilities of positive impacts and minimizing the negative impacts of tourism." (p. 132). Thus, responsible tourism pursues the goals of providing economic and social benefits to the local community by taking into account cultures, traditions and religions, and protecting the natural environment as well as natural resources, and reducing pollution [4].

Sustainable and responsible tourism has received huge resonance in the tourism industry $[4,20]$. Sharing similar underlying values, sustainable and responsible tourism are often used interchangeably [21]. Mathew and Sreejesh [19], however, differentiate between responsible and sustainable tourism, with responsible tourism initiatives building on proper sustainable strategies and policies in order to provide appropriate sustainable actions. Responsible tourism is regarded as one perspective of sustainability in tourism, focusing particularly on the moral and ethical responsibility of engaged stakeholders [9]. For Mihalic [10], sustainability represents the theory or the concept, while responsibility is defined as practice, referring to actual actions. In this regard, responsible tourism implements sustainable, community-focused and pro-poor agendas [10,21]. Sustainable tourism is therefore considered as a concept while its actual application gives rise to responsible tourism. Accordingly, Dávid [11] refers to responsible and sustainable tourism development as requiring a change to behavior and attitudes. Subsequently, responsible tourism constitutes an important part of sustainable tourism, and can be considered as the responsible actions of participants, which include individuals, organizations and sectors, embodying the fundamental requirement for the implementation of sustainable tourism policies [9]. In this context, governance is discussed in the context of responsible tourism, focusing on effective policy instruments and governance models to develop sustainability [22]. Particularly in the area of community-based tourism, good governance and equity through fairness, use and distribution of tourism-related resources, community empowerment, and the stewardship of cultural, natural, and social assets are needed [23]. Following Dias et al. [24] and Bramwell and Lane [25] all stakeholders in a service chain-from destination management organizations (DMOs), tourism companies and local communities, to investors, tour companies and agents, institutions, governments, and tourists-have a meaningful role to play in achieving responsible tourism. Tourism stakeholders are responsible for the consequences and impacts of their behavior [24]. In particular, responsible tourism focuses on behavior and on shaping individuals' attitudes and values [9]. In 
this sense, responsible tourism behavior is defined as, "the process of engaging in actual behavior to achieve a full set of sustainability aims." [10] (p. 468).

According to Higgins-Desbiolles [26], the COVID-19 crisis offers a rare opportunity to rethink tourism with a demand to break with processes and structures of injustice, exploitation, and oppression. In this regard, tourism needs to go beyond responsible approaches and focus on socialized tourism [26]. In the post-crisis period, it is assumed that tourists will focus on responsible travel and tourism experiences [27], requiring the travel industry to move towards more responsible practices [28].

\subsection{The Importance of Environmental Awareness}

The Theory of Planned Behavior (TPB) explains the intentions of an individual as a central factor in achieving a certain behavior [29]. In the TPB, intentions are driven by attitudes towards a favorable type of behavior, and subjective norms such as social pressure and behavioral control [30]. It is assumed that the motivating factors are captured by the intentions which affect actual behavior. These factors are indications of how much of an effort an individual intends to make and how much work they plan to do in order to carry out the desired behavior [29].

In terms of responsible tourism behavior, environmental knowledge and pro-environmental attitudes reinforce each other, particularly in the search for information on environmental issues [31]. Research findings show that environmental knowledge is understood as knowledge and awareness of environmental problems and possible solutions to those problems [32]. Improving knowledge about environmental problems can contribute to increasing people's concern and awareness but does not necessarily lead to behavioral changes [33,34]. However, tourists' pre-existing knowledge before arriving at a destination is described as a fundamental requirement [35] for responsible tourism. Tourist responsibility implies responsible, conscious, ecological and ethical thinking [10], with awareness being defined as the awareness of environmental harm. In this sense, environmental awareness corresponds to the promotion of low carbon tourism and environmental protection, as well as learning about and becoming aware of environmental protection [36].

Pro-environmental attitudes, otherwise, which are related to concrete situations and objects, can have a positive or negative influence on behavior. Alterations in attitudes and values are, however, necessary drivers for action but are not sufficient to change behavior in a foreseeable way [32]. Although it is argued that tourists are increasingly aware of the major importance of conserving cultural and natural resources [37], there often seems to be a discrepancy between tourists' attitudes toward responsibility and their actual behavior [38]. However, there is a strong interconnection between environmental knowledge and pro-environmental attitudes [32].

According to Huang et al. [39], environmental consciousness, referring to tourists' concerns about environmental pollution, environmental damage, as well as issues regarding recycling, determines responsibility. Environmental concerns have a particularly strong personal influence on behavioral outcomes by directly influencing perceptions and assessments of situation-specific cognition [31] which implies that environmental knowledge and information are required [39].

\subsection{Responsible Tourist Behavior}

Caruana, Glozer, Crane and McCabe [8] argue that responsible tourism research has focused on top-down approaches, while the views of tourists have been neglected. For Stanford [13], tourists have been neglected by the responsible tourism debate due to the argument that tourists can lose all sense of responsibility while on vacation. As tourists have the potential to contribute positively to responsible tourism [13], the latter provides a lens for exploring responsible behavior with a view to improving tourism sustainability [9]. Furthermore, tourists can help to minimize negative tourism impacts, some of which are self-generated, by making sustainable vacation choices and by behaving in an environmentally sustainable way during their stay at their respective destinations [40]. 
Responsible tourism behavior entails actions which benefit the pillars of a workable sustainability concept: these relate to economic, socio-cultural, environmental, and institutional aspects $[10,23]$. Institutional aspects in this context refer to governance, with enforcement and policy design contributing to sustainability [41]. For responsible tourists, these dimensions include the concepts of awareness, respect, engagement, reciprocity and excellence, as well as spending money [13]. Responsible tourist behavior thus embraces aspects such as choosing environmentally friendly transportation, purchasing responsible tourism products or incorporating destination communities [38]. The choices tourists make in travel decision-making, including their choice of accommodation and transportation, as well as their choices at the destination with regard to services and products, determine their consumption and sum up their contribution to responsible tourism [38].

When selecting a travel destination, responsible tourism means avoiding mass tourism destinations and switching to other destinations. Responsible tourists may be more influenced to choose destinations that respect the rights of staff, by offering decent and fair working conditions. Moreover, when booking a vacation, the responsible tourist will focus on local tourism agents [24]. In this regard, adequate support from governments is needed to strengthen the responsibility of tourism providers, which, in turn, determines tourists' sense of responsibility [42]. In addition, sustainable transportation, in particular avoiding air travel and opting for public transport, contributes to responsible tourism behavior [43].

At the destination itself, the behavior of tourists determines the wellbeing of the local community [38]. In this regard, responsible tourists are required to respect the local community, the local culture and its traditions, while informing themselves about religion and customs. In addition, they need to be civilized, patient, polite, and participatory [24]. Moreover, respect towards the environment and the community culture were identified by Stanford [13] as elements of responsible tourism behavior. In this regard, tourists need to be educated about environmental issues, while acquiring an awareness of the destination they are visiting [13]. In this context, governance can increase tourists' sense of responsibility by increasing their competence, which forms a virtuous cycle potentially leading to voluntary efforts to protect natural resources by tourism consumers [42]. For Thapa et al. [44], environmentally responsible behavior involves various proportions, such as avoiding purchases to reduce environmental impacts, recycling trash, being involved in communities so as to influence environmental decisions, and being educated about environmental issues. Thus, tourists take responsibility for the environment, by not throwing garbage into the countryside, avoiding unnecessary consumption as well as dangerous or forbidden places at the respective destinations, and complying with environmental rules [24]. Tourist purchases at the respective destination represent a major source of income for destination residents [38], and thus are also defined as tourists caring for the hosts [13]. Therefore, responsible tourism consists in contributing to local trade by purchasing local products and services [24]. Chan and Xin [45] also refer to the provision of benefits for the local community through responsible tourism but add the support of communities to protect the environment. Moreover, engagement as responsible tourist includes interaction with local communities and the environment, while financial contribution refers to the benefit of the local economy [13]. Regarding the avoidance of crowding as part of responsible tourism, Chan and Xin [45] suggest limiting tourist numbers. In addition, responsible tourist behavior consists of acting in a sustainable way, e.g., using public transport [24].

The COVID-19 pandemic is believed to influence tourist travel behavior, such as travel avoidance due to the pandemic [46], perceived travel risk [47], and a change to tourists' psyche [16]. In this context, it is argued that tourist behavior might change in response to their risk perception, in terms of destination choice, shorter travel durations [47] and type of tourism [48]. In a post-pandemic world, tourists are likely to choose destinations that had fewer cases and were better able to cope with the negative consequences [6]. Li, Zhang, Liu, Kozak and Wen [47] also point out that tourists may change their transportation modes as a result of the pandemic and focus on travel by car. In addition, travel insurance, group-level preferences, and known destinations may provide tourists with a level of safety 
that reduces their travel risk perception, while, for example, crowd perception is related to the perceived infectivity of COVID-19 [16]. Regarding this, Sigala [49] predicts that the pandemic will introduce new acceptance levels for perceived crowding, as the COVID-19 pandemic has induced unprecedented levels of anxiety, panic, and fear associated with close human contact [50].

\section{Materials and Methods}

Research on environmentally friendly tourists has largely concentrated on quantitative approaches which aim to operationalize and measure environmentally friendly behavior [40]. However, research on the responsible behavior of tourists seems to be limited [8]. Previous quantitative studies have focused on divergent approaches and as a consequence have led to limited theoretical conclusions [40]. Thus, more, especially qualitative research is needed to understand changes in tourist behavior in response to the current COVID-19 pandemic [16].

Thus, data was gathered by means of semi-structured interviews to explore the responsible behavior of tourists. The interviews allowed the researchers to probe more deeply into interviewees' experiences while also obtaining factual information [51]. The interview guideline was developed with reference to previous studies, consisting of questions dealing with sustainable tourism, responsible tourism, as well as environmental awareness. After pre-testing and adapting the interview questions' wording (see Table 1), 19 in-depth interviews were conducted with responsible tourists in August 2020 (see Table 2). The interviews were all conducted in Innsbruck, Tyrol, Austria. Interviews were held in the German language, with two researchers translating all codes and the respective exemplary quotes to ensure accuracy. The interviewees were selected on the basis of the answers given in a previous study by Dolnicar [52] relating to defined environmentally friendly behavior. Accordingly, the majority of environmentally friendly behavioral approaches had to be answered in the affirmative for individuals to be invited to participate in the study. This procedure allowed the authors to explore responsible tourists' perceptions in greater depth. In particular, the interviews allowed to map tourists' awareness of responsible tourism in light of the COVID-19 pandemic in order to obtain information about their behavioral change. The interviews were conducted face-to-face at the interviewees' place of residence and lasted an average of $25 \mathrm{~min}$.

Table 1. Interview guideline.

\begin{tabular}{lc}
\hline \multicolumn{1}{c}{ Questions } & Reference \\
\hline How often did you go on vacation in 2019 before the current travel restrictions due to COVID-19? & \\
Where to and why? & Juvan and Dolnicar [53] \\
What were your first steps in planning a vacation and do you think about sustainability, e.g., & \\
environment, social status of residents, cost, quality or safety? & Higgins-Desbiolles [17] \\
In terms of your next vacation—-to what extent has COVID-19 influenced your sustainable & Bamberg [31] \\
vacation planning? & Caruana, Glozer, Crane and \\
To what extent do you inform yourself about negative tourism impacts in the destination? & McCabe [8] \\
When you think of a responsible holiday, what comes to mind? & Stanford [13] \\
How do you define responsible tourism? What is your contribution to responsible tourism? To & \\
\hline
\end{tabular}

The collected data was analyzed following the template analysis approach, by transcribing, analyzing, coding, and examining the data with the qualitative data analysis software MAXQDA [54,55]. In this regard, two authors conducted the coding process, firstly by familiarizing themselves with the data, then by carrying out preliminary coding and clustering to produce an initial template. The authors subsequently applied the respective outputs in order to develop the final template and interpret the data (see Table 3) [55]. Thus, the quality of the data analysis was enhanced through individual coding revisions 
and discussions about parallel coding findings [55]. Table 2 provides details of participants and Table 3 illustrates the final coding templates with the respective categories.

Table 2. List of interviewees.

\begin{tabular}{cccc}
\hline ID & Age & Gender & Job \\
\hline 1 & 28 & Female & Student/ editorial assistant \\
2 & 58 & Female & Sales assistant \\
3 & 27 & Male & Microbiologist \\
4 & 67 & Female & Retiree \\
5 & 31 & Male & Insurance agent \\
6 & 26 & Female & Architect \\
7 & 28 & Female & Student/ project assistant \\
8 & 39 & Female & Lawyer \\
9 & 27 & Male & Forester \\
10 & 59 & Male & Retiree \\
11 & 55 & Male & Project leader \\
12 & 37 & Male & CEO \\
13 & 27 & Female & Dietician \\
14 & 55 & Female & Civil servant \\
15 & 44 & Male & Pensioner \\
16 & 72 & Female & Commercial clerk \\
17 & 39 & Female & Construction operator \\
18 & 28 & Male & Student \\
\hline
\end{tabular}

Table 3. Coding template.

\begin{tabular}{|c|c|c|}
\hline Category & Code & Exemplary Quotes \\
\hline \multirow{6}{*}{$\begin{array}{l}\text { Responsible } \\
\text { tourism behavior }\end{array}$} & $\begin{array}{l}\text { Focused on regional } \\
\text { value creation }\end{array}$ & $\begin{array}{l}\text { "Yes, so when you take a vacation in Austria, it's already a contribution to } \\
\text { sustainability, to the support of regional businesses. I will also maintain this in } \\
\text { the future. That the added value simply remains in one's own country, that the } \\
\text { money one earns in Austria is also spent again in Austria and circulated. I think } \\
\text { that is a contribution that is quite good for sustainability." (Interview 8) }\end{array}$ \\
\hline & Avoidance of crowding & $\begin{array}{l}\text { "I wouldn't want to visit anything where there are super many people or crowds. } \\
\text { Rather something remote. In general, the desire has decreased somewhat." } \\
\text { (Interview 9) }\end{array}$ \\
\hline & $\begin{array}{l}\text { Host community } \\
\text { consideration }\end{array}$ & $\begin{array}{l}\text { "Yes, well, if I see sustainability, i.e., ecological or social, then certainly I would } \\
\text { not travel to a country that does not fulfill basic social needs. Where the } \\
\text { residents are suffering totally, I wouldn't go there." (Interview 9) }\end{array}$ \\
\hline & $\begin{array}{l}\text { Focused on } \\
\text { short-haul tourism }\end{array}$ & $\begin{array}{l}\text { "Yes, actually, because I have now generally resolved that I have actually already } \\
\text { seen a lot in the distance and will now rather vacation in the home country. I } \\
\text { think that I can then support the people in the country and thus regionally." } \\
\text { (Interview 13) }\end{array}$ \\
\hline & $\begin{array}{l}\text { Sustainable means } \\
\text { of transport }\end{array}$ & $\begin{array}{l}\text { "Hours of driving, such as to Sweden, I do not like that, I prefer to take the train. } \\
\text { Since I check then already what is more environmentally friendly." (Interview 1) }\end{array}$ \\
\hline & $\begin{array}{l}\text { On-site environmentally } \\
\text { friendly behavior }\end{array}$ & $\begin{array}{l}\text { "Yes, so on vacation I also do not want to have that I get fresh towels every day. I } \\
\text { put the new towels then on the side that the staff knows. I don't think that's } \\
\text { necessary." (Interview 2) }\end{array}$ \\
\hline
\end{tabular}


Table 3. Cont.

\begin{tabular}{|c|c|c|}
\hline Category & Code & Exemplary Quotes \\
\hline \multirow[b]{2}{*}{$\begin{array}{l}\text { Environmental } \\
\text { awareness }\end{array}$} & $\begin{array}{l}\text { Sensitivity to environmen- } \\
\text { tal responsibility }\end{array}$ & $\begin{array}{l}\text { "I think that has to be by itself, the behavior and attitude has to be a basic } \\
\text { attitude. How do I want to make my vacation and how sustainable do I want to } \\
\text { be? Otherwise, it's not worth it." (Interview 14) }\end{array}$ \\
\hline & $\begin{array}{l}\text { Convenient behavior } \\
\text { on vacation }\end{array}$ & $\begin{array}{l}\text { "On vacation, I have to say, there is also this reward factor. You just think to } \\
\text { yourself-yes, now I'll just treat myself and switch off and just don't think about } \\
\text { anything else. It certainly plays a big role that you tend to go by car, even for } \\
\text { short distances that I would probably go by train or subway at home." } \\
\text { (Interview 1) }\end{array}$ \\
\hline \multirow{3}{*}{$\begin{array}{l}\text { Stakeholder } \\
\text { responsibility }\end{array}$} & $\begin{array}{l}\text { Supply side's } \\
\text { responsibility }\end{array}$ & $\begin{array}{l}\text { "Similar to the first point, if there is not obviously the possibility to do without } \\
\text { plastic dishes, because you don't want to worry about it on vacation and } \\
\text { therefore it must be regulated by the provider." (Interview 18) }\end{array}$ \\
\hline & $\begin{array}{l}\text { Tourists' information } \\
\text { procurement }\end{array}$ & $\begin{array}{l}\text { "I think that it is too troublesome for most people to ask every hotel how } \\
\text { sustainable the operators are. The vacation should also be relaxation and if it } \\
\text { begins so stressful with the inquiries. If I catch it badly, I find only with the 20th } \\
\text { hotel something, then one starts the vacation already annoyed. Then they most } \\
\text { simply take what they first like." (Interview 5) }\end{array}$ \\
\hline & $\begin{array}{l}\text { Governmental } \\
\text { responsibility }\end{array}$ & $\begin{array}{l}\text { "I believe that this can only be achieved through taxation. Travel and flying } \\
\text { must simply be as incredibly expensive as it once was where no one could afford } \\
\text { to fly anywhere." (Interview 12) }\end{array}$ \\
\hline
\end{tabular}

\section{Results}

\subsection{Responsible Tourism Behavior}

Increasingly respondents expressed a preference for a regional focus in terms of their sustainable behavior. On the one hand, this refers to consumption at the destination, by focusing on regional products, or visiting regional restaurants. On the other hand, it also embraces their accommodation choices, as small and medium-sized family-owned hotels are preferred over hotel chains, as this quote illustrates, "For me, sustainable vacation is that I go to a hotel or a guesthouse that belongs to a family and perhaps also operates a farm. Just spend the money with such families who are themselves already sustainable in a certain form." (Interview 3)

In addition, the interviewees indicated that they try to avoid large crowds and mass tourism. At the destination, they choose activities that do not involve the risk of crowding, "Where it's not a big group or 100 people doing this activity together, but it's really just done for me." (Interview 9)

The interviews also demonstrated that tourists consider communities at the tourism destinations and accordingly do not condone poor treatment of the residents, "Well, I wouldn't go to a country where I have the feeling that women are extremely discriminated, for example, because I wouldn't feel free. The safety factor certainly plays a role, but especially if I have the feeling that women are not treated well in the country, then I wouldn't want to travel there." (Interview 7)

In addition, the COVID-19 pandemic was discussed not only in terms of policy regulations about traveling, but also in terms of influencing tourists in a more sustainable way. In this sense, the interviewees indicated that they would like to focus more on shorthaul tourism destinations within the country or in neighboring countries, "It has now influenced me in the sense that one becomes aware of one's own region again and also of one's immediate surroundings, and I now also include the neighboring countries. Then you also become more aware, and you find out very quickly that it is actually not necessary to fly somewhere or to go far away to spend a nice and relaxing vacation that also has the incentive that you have a better feeling. Not only because of the distance but also because one is confronted there with another tourism, namely not the masses, but where one already thinks a little more." (Interview 11) 
When it comes to means of transport, interviewees spoke of avoiding air travel for short distances. However, arguments in favor of traveling by plane, especially to long-haul destinations, were also mentioned, especially in the context of flexibility and speed, both of which are important decision-making factors.

"So, if I decide to travel outside of Europe, it doesn't matter because then I have to take a plane anyway because I don't have three months' time to take a container ship across the Atlantic. Within Europe, the mean of transport does play a role." (Interview 7)

In this sense, however, the interviewees spoke about paying a C02 offset charge to compensate for any air travel, as this quote shows, "Definitely more train journeys and if an airplane is used in any case pay the CO2 compensation." (Interview 1)

Increased travel by public transport, such as by bus or train, also demonstrated that car and air travel can be avoided, especially for shorter distances, as this example shows, "Yes, definitely. So, as I said, the flight is already a problem for me. I also make sure that I can always travel by train or bus within Europe, even by car if there is no other way. In the past, I have often taken a longer trip to avoid the plane. And as I said, a long-distance flight is always associated with a bad conscience." (Interview 7)

In addition, interviewees indicated a conscious decision to avoid cruise ship vacations, particularly because of their environmental impact, "I am not on cruises; such things do not interest me. Not only because of the ship, I like sailing, but really because these are real environmental polluters and energy consumers." (Interview 11)

For mobility at the destinations, flexibility plays a major role. Consequently, increased reliance is also placed on the car as a mean of transport. On site, and at the accommodation, tourists also follow various sustainability principles, e.g., the multiple use of towels and the avoidance of garbage and daily cleaning were mentioned.

\subsection{Environmental Awareness}

The respondents indicated that they are aware of the negative impacts and can, therefore, take responsibility for more sustainable development. In particular, the COVID19 pandemic is increasingly being seen as a trigger for reflection, bringing environmental awareness into sharper focus, "So, the environmental aspect plays a big role for me, because the effects are also noticeable for me through COVID-19. That impressed me very much and made me reflect. When you see and experience all the effects of the reduction, it makes a big difference. I will focus much more on sustainability." (Interview 1)

Even though the interviewees are sensitive to environmental harm, their explanations also demonstrate their divergent behavior while on vacation. Findings show that environmentally friendly behavior is strongly focused on the home and plays a less important role at the destination, particularly due to the tourists' need for enjoyment while on vacation, "I think everyone can take a look at themselves and optimize this. Efficient food, sharing resources and recycling. And on vacation it is simply difficult because it is also communicated through the media in such a way that one forgets all the rules and lets oneself fall and pours the champagne and simply indulges in what one would not otherwise indulge in. This is also communicated in this way and the masses also live like this." (Interview 3)

\subsection{Stakeholder Responsibility}

In line with convenient travel behavior, respondents see providers and suppliers as responsible for environmental sustainability. Accommodation providers, airlines, and transportation operators are cited as being responsible for sustainability, e.g., by creating sustainable opportunities and providing relevant information, "I don't know, because tourists are on vacation and lazy to think. I think that if you mention something in the room or on the homepages it is mentioned again and again and is preached then I believe that it stimulates a little bit to think about one or the other." (Interview 8)

For example, the responsibility for $\mathrm{CO} 2$ compensation payments is also shifted to the airlines, "No, but this has only recently become an issue. But I think it's the airline's responsibility to come up with something. It's an economic factor that tickets are becoming 
more expensive, but I don't think it's right to pay compensation on a voluntary basis." (Interview 15)

In this sense, the tourists' information gathering with respect to environmental sustainability was also discussed. Here, results show that tourists try to keep the need for information low and rely on the providers, "I think from both sides. The tourist most likely gives it too little thought. Many just want to go to the destination and think nothing. If they are made attentive however by the operators to it, then the tourist becomes probably also rather ready there to make thoughts about it." (Interview 2)

Interviewees also stated that some responsibility for environmental sustainability lies with the government, e.g., by introducing guidelines regarding certification and/or standards, "How to explore. You just must do it yourself and what's the point. It's like in the supermarket, do I take the meat with the certificate or the other. Is there an organic farmer around the corner, or do I eat seasonally? People can't filter the information at all. You simply must deal with this topic a lot and many people lack access and there is simply too much information that people can no longer filter it. The question is who is responsible for this, and in my opinion, it is the state." (Interview 12)

In addition, taxes were mentioned not only in the context of $\mathrm{CO} 2$ compensation, but also in terms of increasing prices for air travel.

\section{Discussion}

The respective research findings shed light on responsible tourist behavior, by indicating its relevance for sustainability as triggered by the COVID-19 pandemic, while also demonstrating the importance of environmental awareness.

In line with previous research, the results indicate that tourists potentially contribute to economic, socio-cultural, and environmental sustainability by behaving in a responsible manner [10]. While previous studies, especially ERB studies [12], focused mainly on environmental and social sustainability, this study shows that economic sustainability is also of great importance for tourists. In this regard, tourists make local service and product purchases in an attempt to contribute to local trade, corresponding to the studies of Dias, Aldana, Pereira, da Costa and António [24] and Stanford [13]. Additionally, a focus on small and medium-sized family accommodation was discussed as a way of contributing to economic sustainability. Thus, economic sustainability represents a key concern among responsible tourists, allowing the following proposition to be derived:

Proposition 1. Regional value creation, as a factor for economic sustainability, represents a driver for responsible tourist behavior.

Moreover, the results indicate that tourists consider responsibility issues not just on site. For their destination choice, they focus on community concerns, by talking, for instance, about fair conditions for residents, which corresponds to the arguments of Dias, Aldana, Pereira, da Costa and António [24] about fair and decent workers' rights. As Hanna and Adams [43] illustrated in the realm of sustainable transport, respondents prefer to avoid air travel for short distances and see this in terms of responsible tourism behavior, while expressing that flexibility is still a beneficial argument for traveling by plane. In contrast to previous literature suggesting that tourists may shift their transportation choices to self-driving modes due to the pandemic [47], the corresponding research findings indicate that tourists prefer sustainable modes of transportation. This study also shows that tourists avoid crowds and, therefore, mass tourism destinations [24]. This corresponds to previous assumptions in the literature that the COVID-19 pandemic introduces new levels of acceptance for crowds [49], e.g., in terms of crowds being perceived as a consequence of risk perceptions [16].

Proposition 2. Destination choice of responsible tourists is driven by community concerns, sustainable transportation, and mass tourism concerns. 
The COVID-19 pandemic, as discussed in the above results, represents an opportunity to rethink travel behavior and thus incorporate more sustainability. In line with previous research showing that the COVID-19 crisis results in the adaptation of travel habits, destination choices, travel patterns, and tourist awareness $[6,15,16]$, the interviews indicate a shift towards responsible tourist behavior. Corresponding to the TPB, tourists' intentions determine their behavior, which is driven by their attitude toward sustainable tourism [29]. The COVID-19 pandemic thus resulted in an increased awareness that builds on knowledge about environmental problems as well as a favorable attitude toward sustainability, which corresponds to the arguments of Zsóka, Szerényi, Széchy and Kocsis [32] about the relationship between attitude and awareness. In this sense, it is considered that governments can potentially strengthen the responsibility of tourists by improving their competencies [42]. A focus on short-haul tourism was identified among tourists and was triggered by the COVID-19 pandemic. In this context, the present study indicates that the crisis has prompted tourists to spend more vacations in their home country or in neighboring countries and that they will continue to do so in the future, which is consistent with previous research suggesting that tourists' destination choice behavior is likely to change [47]. Therefore, avoiding long journeys (e.g., long-haul flights) and spending their holiday in their home countries makes them feel able to contribute to ecological sustainability and to support the regional economy. Contrary to the assumptions of previous literature that tourists' behavior is determined by their risk perception $[16,46]$, the results do not indicate an increase in tourists' ${ }^{\prime}$ isk perception.

Proposition 3. The COVID-19 pandemic encourages responsible tourist behavior by enhancing environmental awareness.

Additionally, the results indicate responsible tourist behavior on site, with tourists particularly focusing on avoiding garbage, daily cleaning or daily changing of towels, thus, corresponding to Thapa, Graefe and Meyer [44] and Dias, Aldana, Pereira, da Costa and António [24] who conclude that responsible tourists recycle their trash, avoid spreading garbage, as well as generally following environmental rules. These findings also correspond to Dolnicar, Crouch and Long's [40] research on tourists behaving in a sustainable manner during their stay at a destination. However, the study results also highlight that tourists whose behavior tends to be driven by convenience while on vacation rely on the information and offers provided by suppliers. Accordingly, tourists do not want to engage in a timeconsuming search for information because they want to be served by tourism providers. Thus, providers can stimulate responsible tourist behavior by using nudges in various forms [52].

Proposition 4. Nudges contribute to responsible tourism behavior on site by providing information and environmentally friendly solutions for tourists.

The findings illustrate that the interviewees believe that suppliers and providers should increasingly be taken to task to achieve responsible tourism. On the one hand, the provision of information about, e.g., sustainable practices or certificates was mentioned, while on the other, possibilities for behaving responsibly were discussed. The results are in line with the responsible tourism concept which builds on the responsibility of all stakeholders [9] including community residents, DMOs, tourism companies, investors, institutions, tourists, as well as tour companies and agents [24]. Tourists also address governmental responsibility for sustainable development, referring to taxation on air travel or the introduction of regulations, which contributes to the need for effective governance models and policy directives for sustainability development [22]. In addition, governments can increase tourists' sense of responsibility by supporting tourism providers in strengthening their responsibility [42]. Consequently, tourists rely on the providers' information for purchases as well as for the provision of sustainable opportunities, which leads to the following proposition: 
Proposition 5. Responsible tourists perceive that the supply side should be taken to task on responsible tourism.

\section{Conclusions}

The COVID-19 pandemic has not only led to a short-term halt to the entire tourism industry [6], but is also causing tourists to rethink their behavior. Tourists are aware of the importance of sustainable tourism development and their potential behavioral contribution to economic, environmental, and social sustainability [10]. In line with the TPB, tourists gather knowledge about environmental issues and thus adjust their attitude toward sustainability which results in responsible tourism behavior [29,32]. Responsible tourist behavior triggered by the COVID-19 pandemic is specifically focused on short-haul tourism, regional value creation $[13,24]$, concerns for communities and residents, the use of sustainable transportation [43] and concerns relating to mass tourism [24] (see Figure 1). Thus, tourists attempt to behave responsibly both on site, focusing on contributing to the regional economy, as well as in their travel decision-making by excluding mass tourism destinations or destinations which discriminate against local communities. As a result of the COVID-19 pandemic, tourists seem to prefer short-haul tourism destinations while trying to avoid air travel. Figure 1 illustrates how the supply side contributes to responsible tourism by providing opportunities and information for tourists to enhance their responsible behavior.

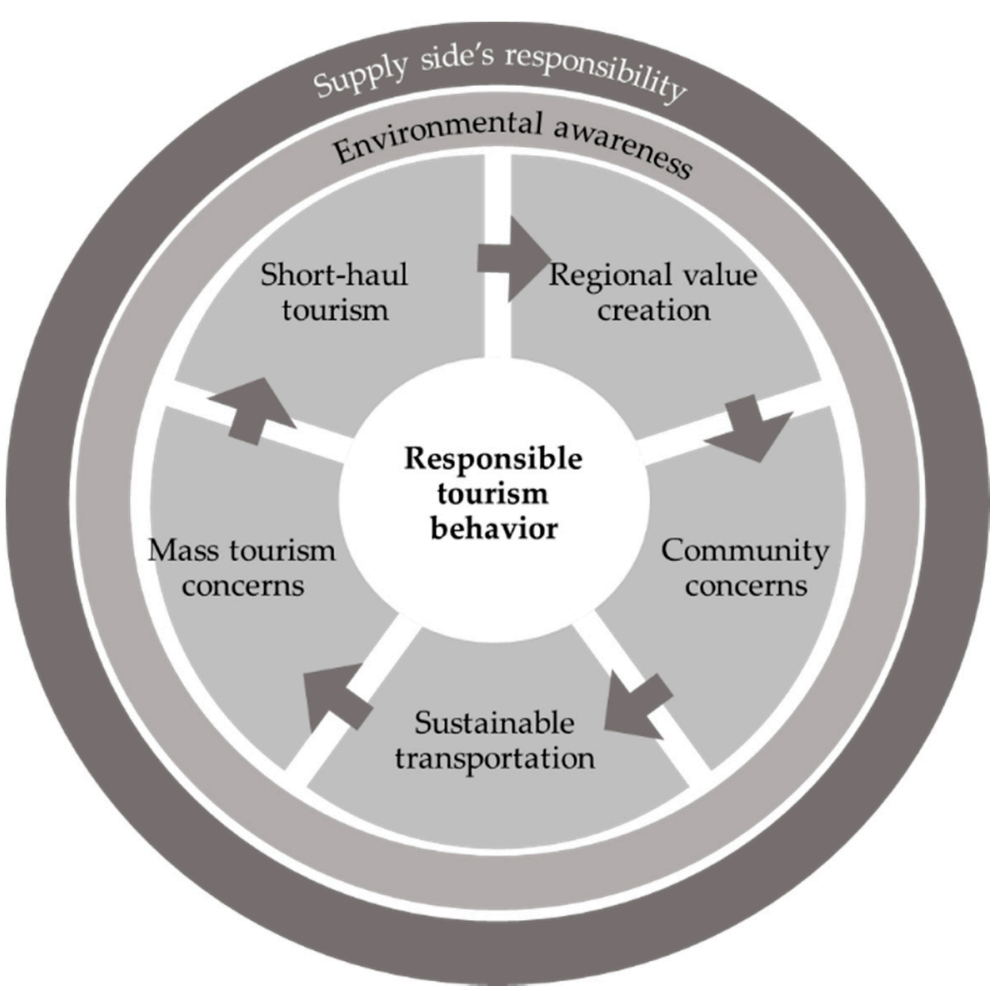

Figure 1. Responsible tourist behavior triggered by the COVID-19 pandemic.

The present study explored the role of tourists in responsible tourism. Hence, the findings contribute to an enhanced understanding of responsible tourist behavior and how that behavior has been triggered by the COVID-19 pandemic. Moreover, the findings of the study add knowledge to the theory-building process of the TPB by indicating that a crisis has the potential to increase knowledge building, which contributes to awareness and, in turn, determines behavior. However, due to the nature of qualitative research, and since the study used one point in time for its data collection, the generalizability of the findings is limited. In this respect, further research is required to investigate tourist behavior in a longitudinal research design, exploring how their behavior has changed following the 
COVID-19 pandemic. Additionally, since the COVID-19 crisis represents an unknown and novel challenge for the tourism industry—as well as for tourists themselves, affecting their current travel habits-future research will be able to investigate actual tourist behavior after the pandemic.

The study findings allow implications to be derived for the practices adopted by tourism suppliers and providers. As demonstrated, tourists assign responsibility for sustainability to the supplier side, particularly regarding the provision of information and opportunities to behave responsibly. In this sense, tourism companies can stimulate the responsible behavior of tourists by using nudges, e.g., by reducing buffets or offering options to avoid daily room cleaning in hotels [52]. The provision of simple and clear information is also of high relevance, e.g., information on regional products can be described to tourists in terms of regional value creation and its significance for the community. In addition, information to support locals and communities can result in more responsible tourist behavior.

Author Contributions: Conceptualization, B.P. and M.H.; methodology, M.H.; software, S.E.; validation, S.E., B.P. and M.P.; formal analysis, S.E. and M.H.; investigation, M.H.; resources, M.P.; data curation, M.H.; writing —original draft preparation, S.E.; writing—review and editing, M.P. and B.P.; visualization, S.E.; supervision, M.P.; project administration, B.P.; funding acquisition, S.E. All authors have read and agreed to the published version of the manuscript.

Funding: This research was funded by Tyrolean Science Fund (TWF) grant number F.18860.

Institutional Review Board Statement: Not applicable.

Informed Consent Statement: Not applicable.

Conflicts of Interest: The authors declare no conflict of interest.

\section{References}

1. Gössling, S.; Peeters, P.; Hall, C.M.; Ceron, J.-P.; Dubois, G.; La Lehmann, V.; Scott, D. Tourism and water use: Supply, demand, and security. An international review. Tour. Manag. 2012, 33, 1-15. [CrossRef]

2. Tran, H.A.T.; Hwang, Y.S.; Yu, C.; Yoo, S.J. The Effect of Destination Social Responsibility on Tourists' Satisfaction: The Mediating Role of Emotions. Sustainability 2018, 10, 3044. [CrossRef]

3. Bramwell, B.; Higham, J.; Lane, B.; Miller, G. Twenty-five years of sustainable tourism and the Journal of Sustainable Tourism: Looking back and moving forward. J. Sustain. Tour. 2017, 25, 1-9. [CrossRef]

4. Fang, W.-T. Responsible Tourism. In Tourism in Emerging Economies; Fang, W.-T., Ed.; Springer Singapore: Singapore, 2020; Volume 50, pp. 131-151.

5. Su, L.; Swanson, S.R.; He, X. A scale to measure residents perceptions of destination social responsibility. J. Sustain. Tour. 2020, 28, 873-897. [CrossRef]

6. Gössling, S.; Scott, D.; Hall, C.M. Pandemics, tourism and global change: A rapid assessment of COVID-19. J. Sustain. Tour. 2021, 29, 1-20. [CrossRef]

7. Pikkemaat, B.; Bichler, B.F.; Peters, M. Exploring the crowding-satisfaction relationship of skiers: The role of social behavior and experiences. J. Travel Tour. Mark. 2020, 37, 902-916. [CrossRef]

8. Caruana, R.; Glozer, S.; Crane, A.; McCabe, S. Tourists' accounts of responsible tourism. Ann. Tour. Res. 2014, 46, 115-129. [CrossRef]

9. Blackstock, K.L.; White, V.; McCrum, G.; Scott, A.; Hunter, C. Measuring Responsibility: An Appraisal of a Scottish National Park's Sustainable Tourism Indicators. J. Sustain. Tour. 2008, 16, 276-297. [CrossRef]

10. Mihalic, T. Sustainable-responsible tourism discourse-Towards 'responsustable' tourism. J. Clean. Prod. 2016, 111, 461-470. [CrossRef]

11. Dávid, L. Tourism ecology: Towards the responsible, sustainable tourism future. Worldw. Hosp. Tour. Themes 2011, 3, 210-216. [CrossRef]

12. Su, L.; Swanson, S.R. The effect of destination social responsibility on tourist environmentally responsible behavior: Compared analysis of first-time and repeat tourists. Tour. Manag. 2017, 60, 308-321. [CrossRef]

13. Stanford, D. 'Exceptional Visitors': Dimensions of Tourist Responsibility in the Context of New Zealand. J. Sustain. Tour. 2008, 16, 258-275. [CrossRef]

14. Mahrouse, G. Feel-good tourism: An ethical option for socially-conscious Westerners? ACME Int. J. Crit. Geogr. 2011, 10, 372-391.

15. Meena, S. Impact of novel Coronavirus (COVID-19) pandemic on travel pattern: A case study of India. Indian J. Sci. Technol. 2020, 13, 2491-2501. [CrossRef] 
16. Kock, F.; Nørfelt, A.; Josiassen, A.; Assaf, A.G.; Tsionas, M.G. Understanding the COVID-19 tourist psyche: The Evolutionary Tourism Paradigm. Ann. Tour. Res. 2020, 85, 103053. [CrossRef] [PubMed]

17. Higgins-Desbiolles, F. The "war over tourism": Challenges to sustainable tourism in the tourism academy after COVID-19. J. Sustain. Tour. 2021, 29, 551-569. [CrossRef]

18. Krippendorf, J. Towards new tourism policies. Tour. Manag. 1982, 3, 135-148. [CrossRef]

19. Mathew, P.V.; Sreejesh, S. Impact of responsible tourism on destination sustainability and quality of life of community in tourism destinations. J. Hosp. Tour. Manag. 2017, 31, 83-89. [CrossRef]

20. Moscardo, G. Using Systems Thinking to Improve Tourism and Hospitality Research Quality and Relevance: A Critical Review and Conceptual Analysis. Tour. Hosp. 2021, 2, 153-172. [CrossRef]

21. Mathew, P.V.; Thankachan, S.S. Responsible and Sustainable Tourism: A Comparison of Community Perceptions. J. Tour. Manag. Res. 2019, 6, 82-92. [CrossRef]

22. Jamal, T.; Camargo, B.A. Tourism governance and policy: Whither justice? Tour. Manag. Perspect. 2018, 25, 205-208. [CrossRef]

23. Dangi, T.B.; Jamal, T. An Integrated Approach to "Sustainable Community-Based Tourism". Sustainability 2016, 8, 475. [CrossRef]

24. Dias, Á.; Aldana, I.; Pereira, L.; da Costa, R.L.; António, N. A Measure of Tourist Responsibility. Sustainability 2021, 13, 3351. [CrossRef]

25. Bramwell, B.; Lane, B. Sustainable Tourism: An Evolving Global Approach. J. Sustain. Tour. 1993, 1, 1-5. [CrossRef]

26. Higgins-Desbiolles, F. Socialising tourism for social and ecological justice after COVID-19. Tour. Geogr. 2020, 22, 610-623. [CrossRef]

27. Ioannides, D.; Gyimothy, S. The COVID-19 crisis as an opportunity for escaping the unsustainable global tourism path. Tour. Geogr. 2020, 22, 624-632. [CrossRef]

28. Rowen, I. The transformational festival as a subversive toolbox for a transformed tourism: Lessons from Burning Man for a COVID-19 world. Tour. Geogr. 2020, 22, 695-702. [CrossRef]

29. Ajzen, I.; Driver, B.L. Application of the Theory of Planned Behavior to Leisure Choice. J. Leis. Res. 1992, 24, 207-224. [CrossRef]

30. Han, H.; Hsu, L.-T.; Sheu, C. Application of the Theory of Planned Behavior to green hotel choice: Testing the effect of environmental friendly activities. Tour. Manag. 2010, 31, 325-334. [CrossRef]

31. Bamberg, S. How does environmental concern influence specific environmentally related behaviors? A new answer to an old question. J. Environ. Psychol. 2003, 23, 21-32. [CrossRef]

32. Zsóka, Á.; Szerényi, Z.M.; Széchy, A.; Kocsis, T. Greening due to environmental education? Environmental knowledge, attitudes, consumer behavior and everyday pro-environmental activities of Hungarian high school and university students. J. Clean. Prod. 2013, 48, 126-138. [CrossRef]

33. Bamberg, S.; Möser, G. Twenty years after Hines, Hungerford, and Tomera: A new meta-analysis of psycho-social determinants of pro-environmental behaviour. J. Environ. Psychol. 2007, 27, 14-25. [CrossRef]

34. Kollmuss, A.; Agyeman, J. Mind the Gap: Why do people act environmentally and what are the barriers to pro-environmental behavior? Environ. Educ. Res. 2002, 8, 239-260. [CrossRef]

35. Wheeler, B. Heritage tourists: Responsible (f) or what? In Critical Debates in Tourism; Singh, T., Ed.; Channel View Publ: Bristol, UK, 2012; pp. 286-290.

36. Cheng, J.; Chiang, A.-H.; Yuan, Y.; Huang, M.-Y. Exploring Antecedents of Green Tourism Behaviors: A Case Study in Suburban Areas of Taipei, Taiwan. Sustainability 2018, 10, 1928. [CrossRef]

37. Saleem, M.A.; Li, J.; Afzal, H. Protect for affinity? The role of destination brand engagement in forming environmentally responsible tourist behaviours. J. Sustain. Tour. 2020, 2, 1-21. [CrossRef]

38. Budeanu, A. Sustainable tourist behaviour? a discussion of opportunities for change. Int. J. Consum. Stud. 2007, 31, 499-508. [CrossRef]

39. Huang, H.-C.; Lin, T.-H.; Lai, M.-C.; Lin, T.-L. Environmental consciousness and green customer behavior: An examination of motivation crowding effect. Int. J. Hosp. Manag. 2014, 40, 139-149. [CrossRef]

40. Dolnicar, S.; Crouch, G.I.; Long, P. Environment-friendly Tourists: What Do We Really Know About Them? J. Sustain. Tour. 2008, 16, 197-210. [CrossRef]

41. Farmaki, A. Regional network governance and sustainable tourism. Tour. Geogr. 2015, 17, 385-407. [CrossRef]

42. Choi, Y.E.; Doh, M.; Park, S.; Chon, J. Transformation Planning of Ecotourism Systems to Invigorate Responsible Tourism. Sustainability 2017, 9, 2248. [CrossRef]

43. Hanna, P.; Adams, M. Positive self-representations, sustainability and socially organised denial in UK tourists: Discursive barriers to a sustainable transport future. J. Sustain. Tour. 2019, 27, 189-206. [CrossRef]

44. Thapa, B.; Graefe, A.R.; Meyer, L.A. Moderator and Mediator Effects of Scuba Diving Specialization on Marine-Based Environmental Knowledge-Behavior Contingency. J. Environ. Educ. 2005, 37, 53-67. [CrossRef]

45. Chan, J.K.L.; Xin, T.K. Exploring Definitions and Practices of Responsible Tourism in Kinabalu National Park, Sabah, Malaysia. J. Tour. Hosp. Manag. 2015, 3, 87-101. [CrossRef]

46. Gupta, V.; Cahyanto, I.; Sajnani, M.; Shah, C. Changing dynamics and travel evading: A case of Indian tourists amidst the COVID 19 pandemic. J. Tour. Futures 2021. ahead-of-print. [CrossRef]

47. Li, Z.Y.; Zhang, S.; Liu, X.Y.; Kozak, M.; Wen, J. Seeing the invisible hand: Underlying effects of COVID-19 on tourists' behavioral patterns. J. Destin. Mark. Manag. 2020, 18, 100502. [CrossRef] 
48. Zeng, B.; Carter, R.W.; De Lacy, T. Short-term perturbations and tourism effects: The case of SARS in China. Curr. Issues Tour. 2005, 8, 306-322. [CrossRef]

49. Sigala, M. Tourism and COVID-19: Impacts and implications for advancing and resetting industry and research. J. Bus. Res. 2020, 117, 312-321. [CrossRef]

50. Zheng, D.N.; Luo, Q.J.; Ritchie, B.W. Afraid to travel after COVID-19? Self-protection, coping and resilience against pandemic 'travel fear'. Tour. Manag. 2021, 83, 104261. [CrossRef]

51. Halperin, S.; Heath, O. Political Research: Methods and Practical Skills, 3rd ed.; Oxford University Press: Oxford, UK, $2020 ;$ p. 506.

52. Dolnicar, S. Designing for more environmentally friendly tourism. Ann. Tour. Res. 2020, 84, 102933. [CrossRef]

53. Juvan, E.; Dolnicar, S. Drivers of pro-environmental tourist behaviours are not universal. J. Clean Prod. 2017, 166, 879-890. [CrossRef]

54. Crabtree, B.F.; Miller, M.A. A template approach to text analysis: Developing and using codebooks. In Research Methods for Primary Care: Doing Qualitative Research; Crabtree, B.F., Miller, W.F., Eds.; SAGE Publications Inc.: Thousand Oaks, CA, USA, 1992; pp. 93-109.

55. King, N.; Brooks, J.M. Template Analysis: For Business and Management Students; SAGE Publications Inc.: Thousand Oaks, CA, USA, 2017; p. 104. 